\title{
PEMBERDAYAAN MASYARAKAT DALAM AGROWISATA BELIMBING DEWA DI KELURAHAN PASIR PUTIH DEPOK
}

\author{
FX Setiyo Wibowo ${ }^{1)}$, Darmawan Damanik ${ }^{2)}$, Aria Dimas Harapan ${ }^{3)}$, Hindun \\ Nurhidayati ${ }^{4}$ \\ ${ }^{1}$ Perhotelan, Sekolah Tinggi Pariwisata Sahid Jakarta \\ ${ }^{2}$ Usaha Perjalanan Wisata, Sekolah Tinggi Pariwisata Sahid Jakarta \\ ${ }^{3}$ Sekolah Tinggi Pariwisata Sahid Jakarta \\ ${ }^{4}$ Sekolah Tinggi Pariwisata Sahid Jakarta
}

\begin{abstract}
ABSTRAK
Tujuan penelitian ini adalah untuk menemukan faktor-faktor yang menyebabkan koperasi dan pabrik pengolahan jus dan sirup tidak beroperasi kembali dan faktorfaktor yang menyebabkan Pemkot Depok belum berhasil mencapai tujuan dalam menciptakan Kelurahan Pasir Putih menjadi lokasi Primatani model kawasan agrowisata serta untuk menemukan model pemberdayaan masyarakat yang cocok untuk menarik masyarakat kelurahan Pasir Putih untuk terlibat dalam program pengembangan agrowisata belimbing. Penelitian ini menggunakan analisis kualitatif deskriptif dengan unit analisis masyarakat dan petani di kelurahan Pasir Putih yang berjumlah 100 informan di beberapa RW dan RT. Data diperoleh dari wawancara mendalam dengan petani, warga, pihak terkait, swasta dan dosen. Didukung dengan FGD (Focus Group Discussion), observasi dan survei serta studi literatur dari berbagai sumber. Disimpulkan bahwa faktor-faktor yang menyebabkan koperasi dan pabrik pengolahan jus dan sirup belimbing adalah pertama, adalah hilangnya rasa memiliki para anggota koperasi. Kedua, koperasi tidak mampu menampung semua hasil panen petani. Ketiga, sebagai pusat koperasi harus mempunyai tiga koperasi primer, yang tidak dimiliki oleh PKPBDD. Sedangkan faktor-faktor yang menyebabkan Pemkot Depok belum berhasil dalam menciptakan kelurahan Pasir Putih sebagai model kawasan agrowisata adalah pertama, menurunnya partisipasi public. Kedua, kurangnya koordinasi antar lintas sektor. Ketiga, tidak adanya pariwisata berbasis masyarakat. sehingga model pemberdayaan masyarakat yang cocok untuk diterapkan adalah Pendekatan 7D.
\end{abstract}

Kata kunci: model pemberdayaan masyarakat, program pengembangan agrowisata, pendekatan 7D, belimbing dewa, kelurahan pasir putih 


\title{
COMMUNITY EMPOWERMENT OF STARFRUIT AGRO- TOURISM IN THE VILLAGE OF PASIR PUTIH DEPOK
}

\begin{abstract}
The goals of this research is to find the factors that cause the cooperatives and processing plant juices and syrups which are not operated; the factors that cause Depok City Government has not been achieved in making the Pasir Putih Village become Primatani location and area of agro-tourism models; and to find a suitable model community empowerment which able to attract Pasir Putih Village community would be actively involved in the development of starfruit agro-tourism program .This study used a qualitative descriptive analysis method with the analysis unit of society and farmers in the village of Pasir Putih totaling 100 respondents spread across several $R W$ and $R T$. The collection of data obtained through in dept interviews with farmers, citizens, related agencies, businesses and lecturer. Furthermore, through FGD, observation and survey and study of literature from various sources. It was concluded that the factors that cause cooperatives and processing plant juice and syrup was stopping operated is first the absence of a sense of belonging of its members. Secondly, the cooperative is not able to accommodate all crop farmers. Third, as a cooperative center should consist of three primary cooperatives, while PKPBDD not have. Furthermore, the factors that cause Depok City Government has not succeeded in making Pasir Putih Village as the location and area Primatani and the model of agrotourism, the first is declining public participation. Second, is the lack of coordination between cross-sector. Third, is due to the lack of community-based tourism. Community empowerment model that is suitable to be applied is a 7D approach.
\end{abstract}

Keywords: community empowerment model,agro-tourism development program, 7D Approaches, Belimbing Dewa, Pasir Putih Village

\section{PENDAHULUAN}

Sektor pariwisata menyediakan pasar untuk menampung produksi pertanian. Sebaliknya sektor pertanian menyediakan berbagai aspek yang dibutuhkan oleh pariwisata. Dengan demikian sektor pariwisata akan mampu meningkatkan permintaan agregat bagi perekonomian di daerah. Dalam artian pekerja di sektor pariwisata memiliki daya beli yang tinggi, mampu membeli barang-barang konsumsi lebih banyak dengan harga tinggi. Salah satu barang konsumsi yang dibeli adalah produksi pertanian, khususnya hasil-hasil hortikultura. Berdasarkan data yang dilansir 
Biro Pusat Stastistik (BPS) dan Pusat Data Informasi (Pusdatin) Kemenparekraf Tahun 2013, jumlah perjalanan wisatawan domestik mencapai 236,7 juta perjalanan dengan total pengeluaran mencapai Rp 156,89 triliun. Beberapa Pemda tingkat Kabupaten salah satunya Bogor, telah jeli memanfaatkan potensi wisatawan domestik tersebut dengan memperbaiki infrastruktur di wilayahnya, seperti menyediakan hotel dan restaurant yang memadai dan standar, membangun sarana jalan dan transportasi yang baik. Dan salah satunya adalah Kelurahan Pasir Putih yang telah ditetapkan oleh Pemkot Depok sebagai lokasi primatani dan kawasan model agrowisata belimbing, diharapkan dapat mengembangkan agrowisata belimbing yang mampu menciptakan pemberdayaan ekonomi bagi sektor pertanian kota di kawasan tersebut.

Dengan membangun Kelurahan Pasir Putih sebagai Lokasi Primatani Belimbing Dewa, pemkot Depok mempunyai harapan akan menjadikannya sebagai pusat pengembangan budidaya tanaman belimbing dewa, karena varietas belimbing ini adalah yang terbaik di Nusantara dan dunia. Jika Anda ingin mencari belimbing, Depoklah tempatnya Menengok sejarahnya, Belimbing Dewa sudah sejak lama dipromosikan sebagai buah andalan Indonesia ke berbagai negara di dunia. Bahkan, belimbing dewa yang dicanangkan Walikota Depok Nur Mahmudi Ismail sebagai ikon Kota Depok sejak tahun 2007, telah menjadi juara dunia dalam kontes internasional di Singapura sebagai belimbing terbesar dan terberat di dunia. Buah unik kebanggaan Kota Depok ini berhasil menyisihkan belimbing asal Australia, Belanda, dan Malaysia dengan berat mencapai 8,6 ons per buah. Tahun 2008, Belimbing Dewa Depok berhasil menjadi juara dunia. (Ketua Kelompok Tani dan Nelayan Andalan (KTNA) Kota Depok, Ririn saat ditemui di Pusat Koperasi Pengembangan dan Pengolahan Belimbing Dewa di Kelurahan Pasir Putih, Kecamatan Sawangan, Bogor, Senin $(26 / 4,2008)$. Belimbing sudah lama dikenal masyarakat. Hingga kini sudah sampai pasaran Eropa. Warnanya kuning kemerahan, ukurannya cukup besar (150 gram 350 gram per buah), serta rasanya manis dan segar karena itu tidak salah, buah ini dijadikan maskot kota Depok sebagai salah satu primadona agrobisnis masyarakat kota Depok Jawa barat. Varietas belimbing Dewa ini banyak dibudidayakan masyarakat Depok di enam kecamatan yaitu Sawangan, Pancoran Mas, Sukmajaya, Cimanggis, Limo dan Beji. Dua petani belimbing dewa yang berhasil dari kecamatan sawangan adalah Suhaimi dan Syukron Muctar.

Namun terlepas dari prestasi yang telah dicapai oleh Belimbing Dewa sebagai varietas terbaik dan usaha pemkot Depok dalam membenahi dan memfasilitasi Kelurahan Pasir Putih sebagai sentra primatani agrowisata sejak tahun 2007, jika dilakukan evaluasi berarti bisa disimpulkan bahwa tujuan tersebut belum tercapai. Hal tersebut dapat ditunjukkan dengan tidak berfungsinya koperasi atau Pusat Koperasi Pemasaran Belimbing Dewa Depok (PKPBDD) sebagai penyalur hasil panen para petani dan juga tidak berfungsinya pabrik pengolahan belimbing jus dan sirup di Kelurahan Pasir Putih. Jika dikaitkan kembali maka program pemberdayaan masyarakatpun belum optimal karena baru sebagian saja partisipasi masyarakat yang terlibat, hal ini terlihat dari sulitnya ditemukan penjual belimbing atau hasil olahan belimbing di sepanjang jalan kelurahan dimulai dari tugu belimbing sebagai gerbang 
kawasan sentra primatani agrowisata belimbing hingga ke dalam. Dari kondisi tersebut dapat disimpulkan bahwa Pemkot Depok belum berhasil dalam mengkomunikasikan buah belimbing sebagai ikon kepada masyarakat Depok pada umumnya dan pada masyarakat Kelurahan Pasir Putih pada khususnya. Ditambah lagi dengan semakin maraknya pembangunan perumahan yang mengurangi lahan pertanian belimbing secara terus menerus. Jangka panjangnya, jika kondisi ini tidak diperhatikan secara serius, maka tujuan dalam menjadikan Kelurahan Pasir Putih sebagai sentra primatani agrowisata belimbing dewa dan sebutan Kota Depok sebagai Kota Belimbing akan hilang dan akan menjadi kenangan saja.

Tabel 1. Daftar Pelanggan PKPBDD

\begin{tabular}{|c|c|c|c|}
\hline No & Pelanggan & Alamat & $\begin{array}{c}\text { Pesanan } \\
\text { Bulanan/Kg }\end{array}$ \\
\hline 1. & PT Carrefour & $\begin{array}{l}\text { Kantor Pusat Carrefour Lt } \\
3 \text { Cr Lebak Bulus Jaksel }\end{array}$ & 7.955 \\
\hline 2. & $\begin{array}{ll}\text { PT } & \text { Makro } \\
\text { Indonesia } & \end{array}$ & Pasar Rebo & 3.733 \\
\hline 3. & PT Lion Superindo & Cikarang Selatan & 1.540 \\
\hline 4. & Total Buah Segar & $\begin{array}{l}\text { Slipi, Kelapa Gading, } \\
\text { Pondok Indah, Wolter M }\end{array}$ & 1.087 \\
\hline 5. & $\begin{array}{l}\text { Jakarta } \\
\text { Market }\end{array}$ & $\begin{array}{l}\text { Kelapa Gading, Green } \\
\text { Ville, Pluit, Gatot Subroto }\end{array}$ & 496 \\
\hline 6. & All Fresh & Pasar Induk Kramatdjati & 283 \\
\hline 7. & $\begin{array}{l}\text { UD Langgeng } \\
\text { Buah }\end{array}$ & Jakarta & 1.234 \\
\hline 8. & Duta Buah & Bekasi & 67 \\
\hline 9. & Top Buah & Gadjah Mada & 92,1 \\
\hline 10. & $\begin{array}{l}\text { Maxim } \\
\text { Market }\end{array}$ & Depok & 86,5 \\
\hline $\begin{array}{l}11 . \\
12 . \\
13\end{array}$ & $\begin{array}{l}\text { UKM Pengolahan } \\
\text { Papa Ho } \\
\text { Pembeli I ain }\end{array}$ & Bogor & $\begin{array}{c}1.736 \\
42,4 \\
124505\end{array}$ \\
\hline 13. & Pembeli Lain & Jumlah & $\begin{array}{l}12.459,5 \\
25.816,5 \\
\end{array}$ \\
\hline
\end{tabular}

Sumber : PKPBDD Tahun 2008

\section{Permasalahan}

1. Faktor apa saja yang menyebabkan tidak beroperasinya koperasi dan pabrik pengolahan jus dan sirup belimbing Kelurahan Pasir Putih ? 
2. Faktor apa saja yang menyebabkan belum tercapainya tujuan Pemkot Depok dalam menjadikan Kelurahan Pasir Putih sebagai lokasi primatani kawasan model agrowisata belimbing ?

3. Model pemberdayaan masyarakat seperti apa yang cocok diterapkan agar masyarakat Kelurahan Pasir Putih mau terlibat aktif dalam program pengembangan agrowisata?

\section{Tujuan Penelitian}

1. Mengetahui faktor apa saja yang menyebabkan tidak beroperasinya koperasi dan pabrik pengolahan jus dan sirup belimbing Kelurahan Pasir Putih

2. Mengetahui faktor apa saja yang menyebabkan belum tercapainya tujuan Pemkot Depok dalam menjadikan Kelurahan Pasir Putih sebagai lokasi primatani dan kawasan model agrowisata belimbing

3. Menerapkan model pemberdayaan masyarakat yang cocok untuk diterapkan agar masyarakat Kelurahan Pasir Putih mau terlibat aktif dalam program pengembangan agrowisata

\section{KAJIAN PUSTAKA}

\section{A. Model Pemberdayaan Masyarakat 7D}

1. Pendekatan 7D

Pendekatan 7D adalah suatu pendekatan yang merangsang munculnya motivasi, berorientasi proses dan bersifat kolaboratif untuk mengelola suatu proyek. Proyek yang dimaksud di sini adalah suatu kegiatan pembangunan masyarakat (community development) dalam aspek tertentu kehidupan misalnya di bidang pertanian, bidang kesehatan, bidang pelestarian lingkungan, dan lain-lain. Dalam pemberdayaan masyarakat semua aspek pembangunan ini hendaklah dipandang sebagai sesuatu yang terpadu satu sama lain (integrated). Pendekatan 7D menerapkan suatu model perencanaan apresiatif yang memusatkan perhatian secara khusus terhadap partisipasi masyarakat. Menurut Dhamotharan (2009) proses perencanaan pembangunan masyarakat dengan pendekatan 7D dimulai dengan memberikan penghargaan terhadap potensi dan prestasi masyarakat serta nilai- nilai murni yang ada dalam masyarakat tersebut. Dilanjutkan kemudian dengan mendorong mereka untuk menyadari ketersediaan sumberdaya yang mereka miliki serta menganalisis kekuatan dan kelemahan mereka. Kesadaran akan semua hal ini akan menumbuhkan motivasi dan rasa percaya diri untuk mengambil alih tanggung jawab tentang masa depan mereka dengan cara merumuskan visi dan tujuan-tujuan. Setelah bersepakat tentang arah yang mereka tuju, masyarakat menyusun rencana mereka dan melaksanakannya dengan memanfaatkan sumberdaya internal dan eksternal yang ada. Agar tahapan-tahapan dalam Pendekatan 7D dapat berjalan dengan efektif keseluruhan prosesnya perlu difasilitasi oleh satu atau beberapa fasilitator. Partisipasi 
masyarakat selama keseluruhan proses merupakan faktor kunci utama dalam Pendekatan 7D. Pada umumnya ada kecenderungan untuk mengartikan partisipasi hanya sekedar sebagai konsultasi atau memberikan kontribusi dalam bentuk uang atau sejenisnya, padahal hakikat partisipasi yang sebenarnya bukan hanya sekedar itu. Partisipasi merupakan suatu proses melibatkan masyarakat dan stockholder lainnya sedemikian rupa sehingga mereka dapat mempengaruhi dan bertanggung jawab dalam proses pengambilan keputusan.

\section{Tahapan Dalam Pendekatan 7D}

Menurut Dhamotharan (2009) Pendekatan 7D terdiri dari tahapan sistematis sebagai berikut:

a. D1-Developing relation (Mengembangkan hubungan).

b. D2-Discovering capacities (Menemukan kapasitas).

c. D3-Dreaming of community future (Membangun cita-cita masyarakat).

d. D4-Directions of community actions (Arah tindakan masyarakat).

e. D5-Designing community actions (Merancang tindakan masyarakat).

f. D6-Delivering Planned Activities (Melaksanakan kegiatan).

g. D7-Documenting Outputs, Outcomes and Learning (Mendokumentasikan hasil dan hal yang dipelajari).

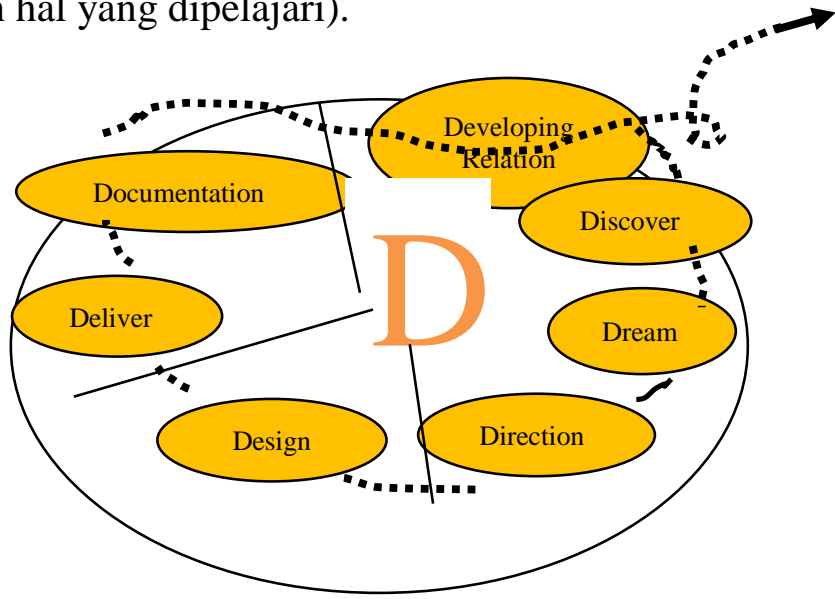

Gambar 1. Model Pemberdayaan Masyarakat Pendekatan 7D Dharmotaran (2009)

Dari tujuh tahapan dalam pendekatan 7D, lima tahapan pertama merupakan tahapan perencanaan kegiatan/proyek yang dilakukan melalui serangkaian pertemuan kelompok masyarakat yang difasilitasi oleh satu atau beberapa orang fasilitator. Tiga tahapan pertama dtiitikberatkan pada menggerakkan aspek emosional manusia dan sangat baik diterapkan dalam suatu suasana yang kreatif dan apresiatif. Tahapan keempat dan kelima memerlukan "kemampuan melakukan analisis" oleh kelompok masyarakat yang mengikuti pertemuan pemberdayaan. Tahapan keenam merupakan pelaksanaan kegiatan-kegiatan berdasarkan rencana yang telah disusun melalui tahapan pertama sampai dengan kelima. Tahapan ketujuh adalah refleksi terhadap keseluruhan proses. 


\section{B. Agrowisata}

Dalam istilah sederhana, agritourism didefinisikan sebagai perpaduan antara pariwisata dan pertanian di mana wisatawan dapat mengunjungi kebun, peternakan atau sawah untuk membeli produk, menikmati pertunjukan, mengambil bagian aktivitas, makan suatu makanan atau melewatkan malam bersama di suatu areal perkebunan atau taman (www.farmstop.com). Sementara definisi lain mengatakan, agritourism adalah sebuah alternatif untuk meningkatkan pendapatan dan kelangsungan hidup, menggali potensi ekonomi petani kecil dan masyarakat pedesaan (www.sfc.ucdavis.edu). Utama (2006) mendefinisikan, agrowisata adalah sebuah sistem kegiatan yang terpadu dan terkoordinasi untuk pengembangan pariwisata sekaligus pertanian, dalam kaitannya dengan pelestarian lingkungan, peningkatan kesajahteraan masyarakat petani. Agrowisata dapat dikelompokkan ke dalam wisata ekologi (eco-tourism), yaitu kegiatan perjalanan wisata dengan tidak merusak atau mencemari alam dengan tujuan untuk mengagumi dan menikmati keindahan alam, hewan atau tumbuhan liar di lingkungan alaminya serta sebagai sarana pendidikan (www.deptan.go.id, 2007). Di beberapa negara, agritourism bertumbuh sangat pesat dan menjadi alternatif terbaik bagi wisatawan, hal ini disebabkan, agritourism akan membawa seseorang mendapatkan pengalaman yang benar-benar berbeda dari rutinitas kesehariannya. Mereka ingin keluar dari kejenuhan, tekanan kemacetan lalulintas, telepon selular, suasana kantor dan hiruk pikuk keramaian. Orang tua ingin anak-anak mereka dapat mengetahui dari mana sebenarnya makanan itu berasal atau mengenalkan bahwa susu itu dari seekor sapi bukan rak supermarket (www.farmstop.com). Utama (2005) menemukan, faktor pendorong wisatawan mengunjungi obyek wisata bertipe ecotourism dan agritourism adalah dominan dipengaruhi oleh faktor relaxation, escape, strengthening family bond, dan play. Kunjungannya untuk memenuhi tujuan penyegaran tubuh, menghilangkan kejenuhan, ajakan teman atau keluarga, dan mencari hiburan atau bermain. Pengembangan agrowisata dapat diarahkan dalam bentuk ruangan tertutup (seperti museum), ruangan terbuka (taman atau lansekap), atau kombinasi antara keduanya. Tampilan agrowisata ruangan tertutup dapat berupa koleksi alat-alat pertanian yang khas dan bernilai sejarah atau naskah dan visualisasi sejarah penggunaan lahan maupun proses pengolahan hasil pertanian. Agrowisata ruangan terbuka dapat berupa penataan lahan yang khas dan sesuai dengan kapabilitas dan tipologi lahan untuk mendukung suatu sistem usahatani yang efektif dan berkelanjutan. Komponen utama pengembangan agrowisata ruangan terbuka dapat berupa flora dan fauna yang dibudidayakan maupun liar, teknologi budi daya dan pascapanen komoditas pertanian yang khas dan bernilai sejarah, atraksi budaya pertanian setempat, dan pemandangan alam berlatar belakang pertanian dengan kenyamanan yang dapat dirasakan. Agrowisata ruangan terbuka dapat dilakukan dalam dua versi/pola, yaitu alami dan buatan (http://database.deptan.go.id). Selanjutnya agrowisata ruangan terbuka dapat dikembangkan dalam dua versi/pola, yaitu alami dan buatan, yang dapat dirinci sebagai berikut. 


\section{Agrowisata Ruang Terbuka Alami}

Obyek agrowisata ruangan terbuka alami ini berada pada areal di mana kegiatan tersebut dilakukan langsung oleh masyarakat petani setempat sesuai dengan kehidupan keseharian mereka. Masyarakat melakukan kegiatannya sesuai dengan apa yang biasa mereka lakukan tanpa ada pengaturan dari pihak lain. Untuk memberikan tambahan kenikmatan kepada wisatawan, atraksi-atraksi spesifik yang dilakukan oleh masyarakat dapat lebih ditonjolkan, namun tetap menjaga nilai estetika alaminya. Sementara fasilitas pendukung untuk kenyamanan wisatawan tetap disediakan sejauh tidak bertentangan dengan kultur dan estetika asli yang ada, seperti sarana transportasi, tempat berteduh, sanitasi, dan keamanan dari binatang buas.

\section{Agrowisata Ruang Terbuka Buatan}

Kawasan agrowisata ruang terbuka buatan ini dapat didesain pada kawasankawasan yang spesifik, namun belum dikuasai atau disentuh oleh masyarakat adat. Tata ruang peruntukan lahan diatur sesuai dengan daya dukungnya dan komoditas pertanian yang dikembangkan memiliki nilai jual untuk wisatawan. Demikian pula teknologi yang diterapkan diambil dari budaya masyarakat lokal yang ada, diramu sedemikian rupa sehingga dapat menghasilkan produk atraksi agrowisata yang menarik. Fasilitas pendukung untuk akomodasi wisatawan dapat disediakan sesuai dengan kebutuhan masyarakat modern, namun tidak mengganggu keseimbangan ekosistem yang ada. Kegiatan wisata ini dapat dikelola oleh suatu badan usaha, sedang pelaksana atraksi parsialnya tetap dilakukan oleh petani lokal yang memiliki teknologi yang diterapkan.

\section{Pariwisata Sebagai Pasar dari Produk Pertanian}

Sektor pariwisata merupakan salah satu lini terdepan dalam memajukan dan meningkatkan perekonomian dan pembangunan nasional. Sebagai bidang yang tidak dapat berdiri sendiri, pariwisata memerlukan dukungan dari sektor pertanian untuk memenuhi seluruh aspek yang dibutuhkan. Oleh karena itu, peluang dari pertanian akan semakin terbuka seiring dengan pemanfaatan produksi yang dihasilkan sebagai salah satu dari kebutuhan pariwisata itu sendiri. Hal ini terjadi karena pariwisata menyediakan pasar bagi produksi pertanian, dimana pasar merupakan salah satu mata rantai yang krusial bagi pembangunan pertanian. Sektor pariwisata menyediakan pasar untuk menampung produksi pertanian. Sebaliknya sektor pertanian menyediakan berbagai aspek yang dibutuhkan oleh pariwisata. Dengan demikian sektor pariwisata akan mampu meningkatkan permintaan agregat bagi perekonomian di daerah. Dalam artian pekerja di sektor pariwisata memiliki daya beli yang tinggi, mampu membel barang-barang konsumsi lebih banyak. 


\section{METODE PENELITIAN}

A. Metode Penelitian dan Unit Analisis

Penelitian ini dilakukan dengan metode kualitatif dengan analisa deskriptif kualitatif. Dengan analisis seperti ini, menurut Bungin (2006:34) paradigma penelitian ini adalah interpretivisme (postpositivisme) dengan tujuan untuk memahami fenomena sosial. Menurut Kirk dan Miler (dalam Moleong, 2002 :3) bahwa penelitian kualitatif adalah suatu tradisi dalam ilmu pengetahuan yang secara fundamental tergantung pada pengamatan pada manusia dalam kawasannya sendiri dan berhubungan dengan orang-orang tersebut dalam bahasanya dan dalam peristilahannya. Mengutip Danim (2002:60-64), ciri-ciri dominan penelitian kualitatif adalah (1) sumber datanya langsung berupa data situasi alami dan peneliti adalah instrument kunci, (2) bersifat deskriptif, (3) lebih menekankan pada makna proses daripada hasil, (4) analisis datanya bersifat induktif, dan (5) makna merupakan perhatian utama dalam pendekatan penelitian. Unit analisisnya adalah seluruh pemangku kepentingan lokasi primatani kawasan model agrowisata belimbing di Kelurahan Pasir Putih yang terdiri dari petani belimbing, pelaku usaha, pejabat pemerintahan, sektor swasta dan warga masyarakat.

\section{B. Sumber Data}

Sumber data dalam penelitia ini, disamping sumber data primer juga sumber data sekunder. Sumber data primer adalah informan, sedangkan sumber data sekunder adalah statistic dan laporan aktivtas masyarakat di kelurahan pasir putih. Sumber data primer antara lain : kondisi sosial ekonomi masyarakat setempat, aset agrowisata, potensi wisata lainnya dan upaya pemberdayaan masyarakat di kelurahan pasir putih. Sedangkan data sekunder antara lain data statistic terkait jumlah kunjungan wisatawan, jumlah petani belimbing, laporan dari dokumen yang terkait upaya pengembangan agrowisata serta program-program pemberdayaan masyarakat yang telah berkembang sebelum penelitian ini dilaksanakan.

\section{Informan}

Informan ditentukan dengan cara purposive. Menurut Arikunto (1989: 113), purposive dilakukan dengan cara mengambil subjek bukan berdasarkan strata, random, atau daerah, tetapi didasarkan atas adanya tujuan tertentu. Informan dalam penelitian ini adalah pengurus sentra primatani agrowisata, pemkot depok, swasta yang bergerak di agrowisata, masyarakat (petani belimbing, petani hortikultura lainnya, tokoh masyarakat, perwakilan masyarakat berdasarkan profesi/pekerjaan), aparat pemerintah (kelurahan, kecamatan dan pemkot) serta pakar pariwisata dari Perguruan Tinggi.

\section{Metode Analisis Data}

Dalam penelitian ini, analisis data dilakukan dengan deskriptif kualitatif dan interpretative dengan didukung oleh hasil pembahasan Focus Discussion Group. 
Analisis data dalam penelitian ini dilakukan dalam beberapa tahap, yaitu (1) mendeskripsikan fenomena pemberdayaan masyarakat di sentra primatani agrowisata, yang merupakan tahapan pengembangan deskripsi yang komprehensif dari hasil penelitian; (2) melakukan verifikasi data terkait pengembangan agrowisata menggunakan pemberdayaan masyarakat ; (3) merumuskan temuan lapanga secara komprehensif yang menjadi focus tempat menyatunya hasil temuan lapangan yang lain dengan mengadakan komparasi atau mencari hubungan antar kelompok yang bermanfaat. Sebagai sebuah penelitian kualitatif, hasil analisis data dalam penelitian ini disajikan secara informal dengan mendeskripsikan secara induktif-analitik dengan kata-kata dan secara formal dengan menggunakan tabel, bagan, serta foto-foto.

E. Tempat dan Waktu Penelitian

Penelitian ini dilaksanakan di Kelurahan Pasir Putih Kecamatan Sawangan Depok Jawa Barat selama 6 bulan mulai dari awal bulan Juli hingga bulan Desember 2014.

Tabel.2 Data, Sumber Data, Informan, Teknik Pengumpulan Data dan Teknik Analisis Data

\begin{tabular}{|c|c|c|c|c|}
\hline Data & $\begin{array}{c}\text { Sumber } \\
\text { Data }\end{array}$ & Informan & $\begin{array}{c}\text { Teknik } \\
\text { Pengumpu } \\
\text { lan Data }\end{array}$ & $\begin{array}{c}\text { Teknik } \\
\text { Analisis } \\
\text { Data }\end{array}$ \\
\hline $\begin{array}{l}\text { Kondisi Sosial } \\
\text { Ekonomi } \\
\text { Masyarakat } \\
\text { Lokasi Primatani } \\
\text { Kawasan Model } \\
\text { Agrowisata }\end{array}$ & Primer & $\begin{array}{l}\text { Pengurus } \\
\text { Lokasi } \\
\text { Primatani } \\
\text { Dan } \\
\text { Kawasan } \\
\text { Model } \\
\text { Agrowisata, } \\
\text { Masyarakat, } \\
\text { Pemerintah } \\
\text { dan Pakar } \\
\text { Pariwisata }\end{array}$ & $\begin{array}{l}\text { Observasi, } \\
\text { wawancara }\end{array}$ & $\begin{array}{l}\text { Deskriptif } \\
\text { kualitatif } \\
\text { didukung } \\
\text { data } \\
\text { kuantitatif } \\
\text { dan hasil } \\
\text { Focus } \\
\text { Group } \\
\text { Discussion }\end{array}$ \\
\hline $\begin{array}{l}\text { Potensi wisata } \\
\text { lainnya }\end{array}$ & Primer & \multirow{3}{*}{$\begin{array}{l}\text { Instansi } \\
\text { Terkait, } \\
\text { Dinas } \\
\text { Kemenpare } \\
\text { kraf, } \\
\text { Deperindag, } \\
\text { Pemkot }\end{array}$} & & \\
\hline $\begin{array}{l}\text { Uapaya } \\
\text { Pengembangan } \\
\text { Agrowisata } \\
\text { Berbasis } \\
\text { Pemberdayaan } \\
\text { Masyarakat }\end{array}$ & Primer & & & \\
\hline Jumlah & Sekunder & & Studi & \\
\hline
\end{tabular}




\begin{tabular}{|c|c|c|}
\hline $\begin{array}{l}\text { Wisatawan } \mathrm{Ke} \\
\text { Kelurahan Pasir } \\
\text { Putih }\end{array}$ & & Dokumen \\
\hline $\begin{array}{l}\text { Jumlah Petani } \\
\text { Belimbing }\end{array}$ & Sekunder & \\
\hline $\begin{array}{l}\text { Program } \\
\text { Pemberdayaan } \\
\text { Masyarakat } \\
\text { Dalam } \\
\text { Agrowisata } \\
\text { Sebelum } \\
\text { Penelitian ini } \\
\text { dilakukan }\end{array}$ & Sekunder & \\
\hline
\end{tabular}

\section{HASIL DAN PEMBAHASAN}

\section{A. Profil Kelurahan Pasir Putih}

1. Data Demografi dan Administratif Kelurahan Pasir Putih

a. Jumlah Penduduk Berdasarkan Kategori

Jumlah penduduk Kelurahan Pasir Putih adalah 16.086 jiwa, adapun jika dibagi per kategori adalah sebagai berikut:

Tabel 3. Penduduk Berdasarkan Kategori

\begin{tabular}{lll}
\hline No & \multicolumn{1}{c}{ Kategori } & \multicolumn{1}{c}{ Jumlah } \\
\hline 1 & Laki-laki & 8.992 orang \\
2 & Perempuan & 7.094 orang \\
3 & Jumlah KK & $4300 \mathrm{KK}$ \\
4 & Jumlah Penduduk Miskin & 300 orang \\
5 & Jumlah Penduduk Buta Aksara Latin dan Al'Quran & 180 orang \\
\hline
\end{tabular}

\section{Sumber : Statistik Kel Pasir Putih 2010}

Dari tabel di atas ditunjukkan bahwa masih terdapt 300 penduduk miskin, hal ini merupakan peluang yang tepat bagi dilaksanakannya pemberdayaan masyarakat, sebab salah satu outputnya adalah terciptanya lapangan pekerjaan yang akan berpengaruh timbulnya ekonomi kreatif. Selanjutnya dampaknya adalah 
beredarnya"uang baru" yang dibawa oleh pengunjung untuk meningkatkan pendapatan dan konsumsi masyarakat lokal.

b. Jumlah Penduduk Berdasarkan Usia

Tabel 4. Penduduk Berdasarkan Usia

\begin{tabular}{lcc}
\hline No & Usia & Jumlah \\
\hline 1. & $0-5$ th & 1920 orang \\
2. & $6-10$ th & 1581 orang \\
3. & $11-15$ th & 1239 orang \\
4. & $16-20$ th & 1429 orang \\
5. & $21-25$ th & 1304 orang \\
6. & $26-30$ th & 1362 orang \\
7. & $31-35$ th & 1383 orang \\
8. & $36-40$ th & 1258 orang \\
9. & $41-45$ th & 928 orang \\
10. & $46-50$ th & 755 orang \\
11. & $51-55$ th & 551 orang \\
12. & $56-60$ th & 421 orang \\
13 & 60 th ke atas & 655 orang \\
\multicolumn{3}{c}{ Sumber : Statistik Kel. Pasir Putih 2010 }
\end{tabular}

Dari tabel ditunjukkan bahwa rata-rata angkatan kerja produktif berjumlah di atas 1300 orang. Mereka berkisar usia 21-45 tahun. Hal ini sangat mendukung untuk dilaksanakannya program pemberdayaan masyarakat.

c. Jumlah Penduduk Berdasarkan Usia Kerja

Tabel 5. Penduduk Berdasarkan Usia Kerja

\begin{tabular}{lcc}
\hline No & Usia Kerja & Jumlah \\
\hline 1. & $19-25$ th & 1.691 orang \\
2. & $26-45$ th & 4.931 orang \\
3. & $46-59$ th & 1.727 orang \\
\hline \multicolumn{3}{c}{ Sumber : Statistik Kel. Pasir Putih 2010 }
\end{tabular}

Dari tabel di atas ditunjukkan bahwa jumlah penduduk berdasarkan usia kerja paling banyak adalah usia 26-45 th, yang digolongkan sebagai usia muda. Identiknya usia muda masih penuh dengan kreatifitas, ide cemerlang, semangat ynag tinggi dan kerja keras. Hal ini sangat mendukung terhadap gerakan pemberdayaan masyarakat tentang sadar wisata agrowisata Belimbing Dewa di Kelurahan Pasir Putih. 
d. Mobilitas Penduduk Th 2011

\begin{tabular}{|c|c|c|}
\hline No & Mobilitas & Jumlah \\
\hline 1. & Lahir & 100 orang \\
\hline 2. & Datang & 155 orang \\
\hline 3. & Meninggal & 77 orang \\
\hline 4. & Pindah & 103 orang \\
\hline
\end{tabular}

Sumber : Statistik Kel.Pasir Putih 2011

Dari tabel ditunjukkan bahwa pendatang berjumlah paling besar dan pada umumnya warga pendatang biasanya berasal dari daerah lain yang bekerja di Jakarta ataupun perantau yang mempunyai karakter terbuka dan semangat untuk membangun daerah yang ditinggali. Hal ini sangat berharga sekali bagi pemerintah local untuk menggandeng mereka dalam mengembangkan daerah.

2. Iventarisasi

a. Kunjungan wisatawan

Berdasarkan wawancara dengan pihak pengelola Taman Wisata Pasir Putih, disampaikan bahwa kedatangan pengunjung di hari weekend sekitar 300 orang, sementara di hari Lebaran bisa mencapai 8.000 orang. Adapun jumlah kunjungan di Pondok Zidane dan d'Kandang Farming Education belum didapatkan secara pasti.

1) Pondok Zidane

2) Taman Wisata Pasir Putih

3) D'Kandang Farming Education

b. Potensi Agrowisata

Jika dilihat dari luas lahannya, Kelurahan Pasir Putih mempunyai 500 hektar lahan, dimana 150 hektar terdiri $60 \%$ lahan pertanian dan $40 \%$ lahan peternakan. Pertanian terdiri dari belimbing, jambu merah, pepaya dan pisang sedangkan peternakannya adalah ayam, ikan, sapi perah dan sapi potong, domba serta kambing atawa. Sementara dari konjungtur tanah adalah lahan hijau berbukit dan berlembah yang masih asri.

1) Pertanian Belimbing Dewa

2) Pertanian Jambu Merah

3) Pertanian Pepaya

4) Suasana Pedesaan Yang Masih Asri

5) Peternakan

a) Sapi perah 
b) Domba

c) Kambing atawa

d) Ayam

e) Pengolahan yoghurt

f) Pengolahan pupuk kandang

g) Atraksi wisata ( memetik buah belimbing dewa, memanen buah belimbing dewa, melihat bunga, membungkus buah belimbing, mengepak, mendengarkan penjelasan dari petani tentang perawatan belimbing, membeli produk olahan, naik sampan, memancing, naik delman, berpawai keliling desa, outbond, dll)

3. Aksesbilitas dan amenitas
a. Terminal Angkot Sawangan di depan gerbang menuju Kel. Pasir Putih
b. Jalan desa
c. Tugu belimbing selamat datang
d. PKPBDD
e. Pabrik pengolahan jus belimbing
f. Penginapan
g. Pusat kuliner

\section{B. Identitas Responden}

Berdasarkan survei yang dilaksanakan pada tanggal 14 dan 22 September 2014 terhadap 100 responden yang terdiri dari petani belimbing dan warga masyarakat di RT 04 dan 06 RW 02, RT 02 RW 03, RT 03 dan 04 RW 04 dan RT 04 RW 09 Kelurahan Pasir Putih, Kec. Sawangan Depok diperoleh hasil sebagai berikut :

1. Berdasarkan Jenis Kelamin

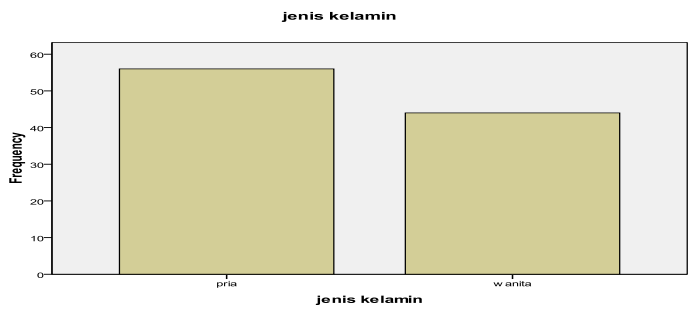

Dari gambar tsb ditunjukkan bahwa dari 100 orang responden, sebagian besar adalah pria. Hal ini menunjukkan bahwa sebagian besar dari pelaku pertanian belimbing adalah kaum pria 
2. Berdasarkan Usia

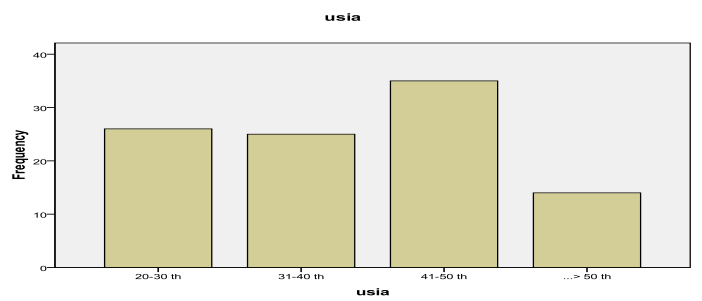

Dari gambar tsb, ditunjukkan dari 100 responden, sebagian besar responden berusia dalam penduduk usia produktif (15-64 tahun), yaitu terbanyak adalah dari usia 41-50 tahun, kemudian usia 20-30.

3. Berdasarkan Pekerjaan

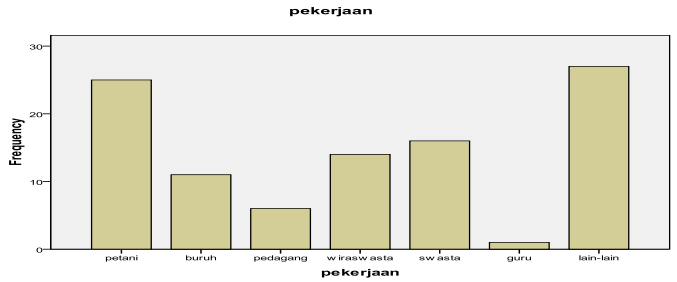

Dari gambar tsb ditunjukkan bahwa sebagian besar responden berprofesi lain-lain, yaitu ibu rumah tangga atau profesi yang tidak tercantum, seperti PNS. Berikutnya adalah petani belimbing

4. Berdasarkan Pendidikan

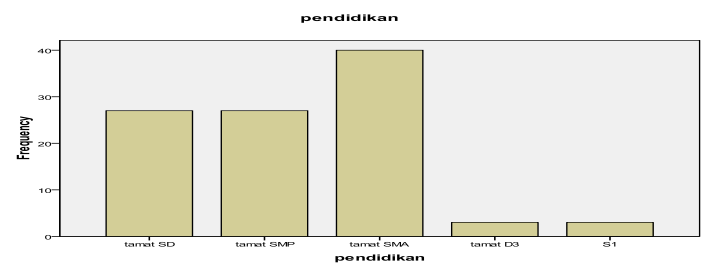

Dari gambar tsb ditunjukkan sebagian besar responden berpendidikan SMA. Hal ini menunjukkan sebagian responden mempunyai wawasan yang cukup untuk berkembang dan terbuka. Apalagi terdapat juga yang berpendidikan D3 dan S1. 
5. Sikap Masyarakat Terhadap Pengembangan Agrowisata

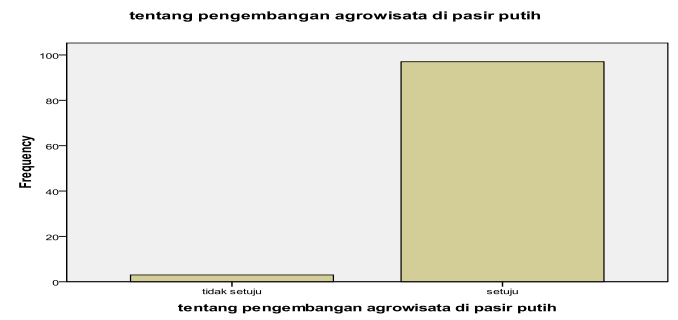

Dari gambar tsb, ditunjukkan bahwa masyarakat setuju akan dilaksanakannya program pengembangan agrowisata belimbing di kel.Pasir Putih. Setuju, sebab diharapkan dari program tersebut akan menghasilkan penghasilan tambahan dan menyerap banyak tenaga kerja.

6. Tanggapan Masyarakat tentang Kesiapan Terlibat

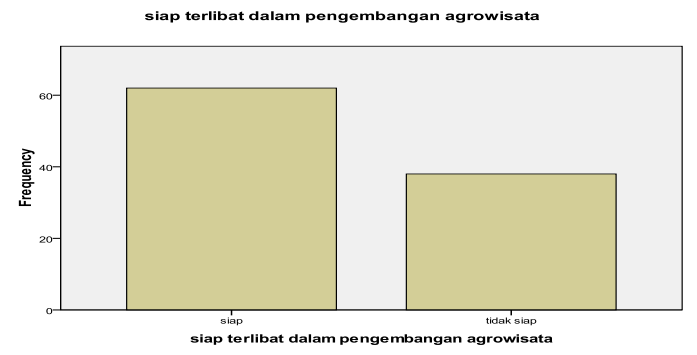

Dari gambar 7 ditunjukkan bahwa masyarakat siap terlibat dalam program pengembangan agrowisata belimbing jika dibutuhkan. Mereka siap terlibat karena menganggap bahwa program ini positif.

\section{Faktor-Faktor Yang Menyebabkan Tidak Berfungsinya Koperasi PKPBDD dan Pabrik Pengolahan Jus dan Sirup}

PKPBDD (Pusat Koperasi Pemasaran Belimbing Dewa Depok) didirikan pada tanggal 30 Oktober 2007 berdasarkan surat keputusan Menteri Koperasi dan Usaha Kecil Menengah No. SK/04/X/2007, sedangkan operasionalnya dilaksanakan mulai tahun 2008. Tujuan PKPBDD yaitu untuk meningkatkan keuntungan petani belimbing dan diharapkan berfungsi sebagai lembaga keuangan mikro agribisnis yang dapat memfasilitasi permodalan petani. Tugas utama PKPBDD adalah memasarkan belimbing segar dan olahannya. PKPBDD sebagai lembaga diharapkan mampu mengatasi fluktuasi harga belimbing, sehingga akan berdampak pada peningkatan kesejahteraan petani belimbing.

Modal utama PKPBDD berasal dari bantuan pemerintah melalui Program Penanggulangan Kemiskinan Indeks Pembangunan Manusia (PPK-IPM) Propinsi Jawa Barat senilai satu milyar untuk belimbing segar dan Rp 400.000.000,00 untuk 
produk olahan belimbing. Sistem pengembalian bantuan modal ini dilakukan dengan cicilan sebesar Rp 10.000.000,00 tiap bulan. Pada tahun 2009 diusahakan kredit dari Bank Mandiri melalui Program Kredit Bina Lingkungan (PKBL) untuk petani, dengan bunga enam persen pertahun. Besarnya pinjaman yang diberikan Bank Mandiri kepada petani berkisar antara Rp 5.000.000,00 sampai Rp 20.000.000,00. PKPBDD berperan sebagai fasilitator dalam PKBL ini, dimana petani tidak perlu memberikan agunan sebelum mengajukan kredit. Sistem pengembalian pinjaman dilakukan dengan cara memotong uang tabungan petani untuk tiap bulannya.

Berdasarkan observasi dan survei dislmpulkan bahwa perusahaan pengolahan belimbing yang seharusnya dapat menyerap belimbing pada saat panen raya belum bisa melakukan produksi dengan optimal karena terkendala dalam pemasarannya. Keberadaan Primatani sebagai sarana adopsi teknologi inovatif belum bisa terserap oleh petani dan belum dirasakan manfaatnya secara nyata oleh petani. Berdasarkan analisis deskriptif dan teori koperasi, penamaan Pusat Koperasi Pemasaran Belimbing Dewa Depok kurang tepat diberikan, karena nama pusat koperasi seharusnya merupakan koperasi sekunder yang terdiri dari tiga koperasi primer belimbing. Dan hal itu tidak terdapat pada PKPBDD ini. Sumber permodalan koperasi seharusnya terdiri dari simpanan pokok, simpanan wajib dan hibah. Sedangkan pada PKPBDD sumber permodalannya hanya dari bantuan pemerintah melalui program PPK-IPM, hal inilah yang menyebabkan rasa memiliki dari para anggota PKPBDD masih rendah. Seharusnya koperasi dibentuk atas dasar kesadaran para anggotanya untuk memajukan kepentingan bersama. Dari faktor-faktor tersebut, sehingga koperasi ini akhirnya berhenti. Berikut table penerimaan dan penjualan belimbing di PKPBDD bulan januari-desember tahun 2008 .

Tabel 7. Penerimaan dan Penjualan Belimbing di PKPBDD Bulan Januari-Desember 2008

\begin{tabular}{ccccc}
\hline No & Bulan & $\begin{array}{c}\text { Penerimaan } \\
(\mathbf{K g})\end{array}$ & Penjualan $(\mathbf{K g})$ & Selisih $(\mathbf{K g})$ \\
\hline 1. & Jan & 55.700 & $17.861,5$ & $37.838,5$ \\
2. & Feb & 61.800 & $31.504,5$ & $30.295,5$ \\
3. & Mar & 19.700 & $16.972,5$ & $2.727,5$ \\
4. & Apr & 27.100 & $25.146,6$ & $1.953,4$ \\
5. & Mei & 31.600 & $25.962,7$ & $5.637,3$ \\
6. & Jun & 49.900 & $46.499,0$ & $3.401,0$ \\
7. & Jul & 25.500 & $24.147,0$ & $1.353,0$ \\
8. & Agus & 30.000 & $27.635,1$ & $2.364,9$ \\
9 & Sep & 35.800 & $29.742,0$ & $6.058,0$ \\
10 & Okt & 10.800 & $10.335,0$ & 465,0 \\
11 & Nov & 18.500 & $17.775,0$ & 725,0 \\
12 & Des & 19.500 & $16.592,0$ & $2.908,0$ \\
\hline
\end{tabular}

Sumber : PKPBDD Th 2008 


\section{Faktor-Faktor Yang Menyebabkan Pemkot Depok Belum Berhasil Dalam Menjadikan Kel Pasir Putih sebagai Lokasi Primatani dan Kawasan Model Agrowisata Belimbing}

\section{Menurunnya Partisipasi Masyarakat}

Sejak tahun 2007 tidak sedikit prestasi yang diperoleh oleh Kelurahan Pasir Putih. Yang pertama, penghargaan yang diberikan oleh Menteri Pertanian Anton Apriantoro kepada kelompok tani Makmur Sejahtera Kec. Sawangan atas usaha budidaya buah yang baik (Good Agriculture Practices/GAP) buah. Kedua, berjalannya proses produksi di PKPBDD hingga berhasil mencapai 25,8 ton rata-rata per bulan. Ketiga, terpilihnya buah belimbing dewa sebagai juara dunia pada tahun 2008. Dari ketiga prestasi tersebut mampu memotivasi masyarakat petani untuk terlibat aktif dalam bertani dan mengembangkan agrowisata belimbing. Namun, setelah tidak beroperasinya koperasi dan pabrik pengolahan belimbing, maka masyarakatpun tidak seaktif seperti semula. Hal ini didukung dari hasil survey terhadap 100 orang responden yang terdiri dari petani belimbing dan warga masyarakat.

2. Kurangnya Koordinasi Antar Sektor Yang Menyebabkan Terjadinya Tumpang Tindih Kebijakan

Hal ini bisa dilihat ketika maraknya pembangunan proyek property perumahan yang cepat dan mengakibatkan berkurangnya lahan pertanian belimbing dengan cepat. Seharusnya, jika telah ditetapkan sebagai kawasan model agrowisata maka harus didukung dengan kebijakan yang membatasi pembangunan proyek property, sehingga terlihat tumpang tindih. Di sisi lain penempatan TPA (Tempat Pembuangan Akhir) di Kelurahan Pasir Putih otomatis menyebabkan bau yang kurang sedap dan akhirnya mengganggu para pengunjung yang datang ke obyek wisata. Berikutnya adalah penggunaan lahan hijau untuk pembangunan perumahan. Seharusnya jika telah ditetapkan sebagai lokasi prima tani dan kawasan model agrowisata, lahan yang ada harus ditambah, bukan sebaliknya dikurangi. Tujuan antara Dinas Tata Ruang Kota dengan Dinas Pertanian serta Dinas Pariwisata harus sinkron dalam menjaga lahan hijau agar tetap lestari. Dibutuhkan tindakan tegas di lapangan bagi yang melanggar aturan penggunaan lahan hijau untuk pembangunan perumahan. Diperlukan pengawasan yang ketat dari tingkat Pemkot, Kecamatan hingga Kelurahan.

\section{Belum Adanya Pariwisata Berbasis Masyarakat}

Terjadinya kunjungan ke Kelurahan Pasir Putih adalah karena adanya 3 obyek wisata yang dikelola oleh swasta yang bermodal besar, yaitu Taman Wisata Pasir Putih, Pondok Zidane dan d'Kandang. Adapun keterlibatan masyarakat masih sangat 
sedikit. Dinataranya adalah Bp. Suhaimi yang berperan dalam memberikan penyuluhan dan presentasi tentang bagaimana menanam, memelihara dan memanen belimbing kepada para pengunjung yang sebagian besar berasal dari sekolah dan perguruan tinggi. Kemudian didukung oleh para home industri yang menjelaskan tentang pengolahan belimbing menjadi produk turunan dan pemasarannya. Sedangkan dari masyarakat baru beberapa saja yang menjual buah atau hasil olahan ke pengunjung, belum dikembangkan. Cinderamata atau soveinir dari belimbing belum dipajang didisplay khusus yang disediakan bagi pengunjung. Dalam pariwisata berbasis masyarakat adalah diperlukan peran utama yaitu keterlibatan yang tinggi dari masyarakat lokal.

\section{E. Model Pemberdayaan Masyarakat Yang Cocok Diterapkan Agar Masyarakat Kel. Pasir Putih Mau Terlibat Aktif Dalam Pengembangan Agrowisata Belimbing}

Adalah model pemberdayaan dengan Pendekatan 7D. Berikut adalah hasil percobaan tahapan awal dari langkah pertama hingga terakhir dalam implementasinya :

1. Menjalin hubungan (Developing relation)

a. STP Sahid dengan kelurahan

Hubungan yang dijalin masih sebatas koordinasi untuk kegiatan penelitian yang dilakukan. Sudah terbangun kerjasama yang baik, lancar. Namun belum sampai pada tahap membuat program bersama untuk pengembangan agrowisata belimbing

b. STP Sahid dengan petani

Petani terbuka dan selalu menyempatkan waktu untuk berdiskusi, sehingga banyak informasi yang diperoleh. Permasalahan yang dihadapi mereka adalah bantuan modal, irigasi, terbentuknya koperasi untuk kesejahteraan mereka dan terlepas dari jeratan tengkulak serta pelatihan untuk pengolahan hasil belimbing.

c. Kelurahan dengan petani

Hubungan telah terjalin lama namun belum dipastikan apakah telah terjaling kepercayaan di antara kedua pihak, dibuktikan dengan sulitnya petani dikumpulkan di kelurahan.

d. $\quad$ STP Sahid dengan pelaku usaha Home Industry

Permasalahan yang dihadapi pelaku usaha home industri dan solusi pemecahannya. Pertama, mereka membutuhkan bantuan atau dukungan dalam bentuk SK dari pemkot yang ditujukan bagi para pengelola obyek 
wisata agar memberikan display khusus untuk memajang produk hasil olahan. Kedua, mereka membutuhkan penyuluhan tentang pengemasan dan pemasaran. Ketiga mereka membutuhkan pasokan belimbing yang stabil dari petani, tidak sebatas pada musim panen saja.

e. STP Sahid dengan warga masyarakat

Hubungan yang telah dijalin adalah dengan adanya pelatihan tentang pembuatan dodol berbahan baku belimbing. Disimpulkan bahwa mereka belum pernah mengikutinya dan mereka antusias mengikutinya. Mereka mempunyai keinginan untuk membuka usaha namun terkendala modal.

f. STP Sahid dengan Dinas Pariwisata Depok

Pada intinya STP Sahid diberi kesempatan untuk melaporkan hasil penelitiannya sebagai rekomendasi bagi Dinas Pariwisata untuk mengajukan dana ke Kementrian Pariwisata

g. STP Sahid dengan Pengelola Obyek Wisata

Dapat disimpulkan bahwa pengelola memberikan kontribusi kepada masyarakat local melalui kegiatan silahturohim pada saat Lebaran, pemberian diskon tiket masuk, penerimaan karyawan dan penyediaan display bagi penjual local. Kendala yang dihadapi adalah kurangnya lahan parkir dan rusaknya akses jalan menuju lokasi.

\section{Menemukan kapasitas (Discovering capacities)}

Pihak kelurahan telah banyak memberikan kontribusi bagi pengembangan agrowisata, terutama karena koordinasi dengan para petani berupa penyuluhan dan pembinaan. Sedangkan Dinas Pariwisatapun selalu mempromosikan potensi agrowisata belimbing ke luar daerah.

3. Membangun Cita-Cita Masyarakat (Dreaming of Community Future)

Dari petani diperoleh cita-cita yaitu mengharapkan adanya bantuan modal dari pihak bank, dibangunnya kembali saluran irigasi, sehingga lahan tidak kekeringan pada saat musim kemarau atau sebaliknya, didirikannya koperasi untuk petani, diadakannya pelatihan pengolahan hasil belimbing, dan perbaikan harga jual belimbing. Sedangkan dari sisi pelaku usaha home industri adalah diberikannya display khusus untuk menjual produk olahan mereka di obyek-obyek wisata yang ada di kelurahan, diberikannya pelatihanpelatihan tentang pengemasan dan pemasaran, diperolehnya pasokan belimbing secara mudah, dan dikenalnya produk-produk olahan dari belimbing sebagai oleh-oleh khas dari Depok. Sedangkan cita-cita warga masyarakat secara umum adalah terciptanya lapangan pekerjaan baru, terkenalnya Kelurahan Pasir Putih sebagai kawasan model agrowisata belimbing dan dibangunnya jalan yang rusak agar mudah dicapai. 
4. Arah Tindakan Masyarakat (Directions of Community Action)

Fokus pada tahap ini adalah menetapkan tujuan yang jelas yang menjadi arah yang jelas bagi kegiatan-kegiatan masyarakat tersebut. Meskipun belum ada komitmen bersama secara tegas, akan tetapi telah dapat dilihat tujuan yang akan dicapai, yaitu :

\section{a. Bagi Para Petani Belimbing}

1) Mengajukan bantuan modal terhadap sektor perbankan

2) Membangun kembali saluran irigasi

3) Mendirikan koperasi bagi petani

4) Mengikuti pelatihan tentang pengolahan belimbing

5) Mencari solusi untuk memperbaiki harga jual belimbing

b. Bagi para pelaku usaha home industri

1) Memperjuangkan untuk mendapatkan display khusus untuk menjual produk hasil olahan di obyek-obyek wisata

2) Mengikuti pelatihan pengemasan dan pemasaran

3) Mencari strategi agar mendapatkan pasokan belimbing yang stabil

4) Mengikuti pelatihan tentang pengemasan dan pemasaran

5) Gencar dalam memproduksi, memasarkan dan mempromosikan produk olahan, sehingga belimbing dikenal masyarakat sebagai ikon kota Depok.

c. Bagi warga masyarakat secara umum

1) Akan terlibat aktif dalam program melalui pembukaan usaha baru khususnya dalam memproduksi produk olahan atau menjual soveinir berbahan baku belimbing

2) Akan terlibat dalam mempromosikan Kelurahan Pasir Putih kepada saudara, teman, kerabat dan orang lain sebagai kawasan model agrowisata Tetap menjaga, merawat dan melestarikan pohon belimbing sebagai asset yang harus dijaga agar tidak punah bahkan bisa berkembang

5. $\quad$ Merancang Tindakan Masyarakat (Designing Community Actions)

Bentuk rencana dapat berupa Kerangka Kerja Logis (Logical Framework), Matriks Rencana Proyek atau Rencana Aksi, atau bentuk lain yang lebih sederhana yang dapat dipahami oleh masyarakat. Untuk tahap yang ke-5 ini belum ada, direncanakan pada tahap penelitian yang ke-2

6. Melaksanakan Kegiatan (Delivered Planned Activities)

Fokus tahap pelaksanaan kegiatan adalah melaksanakan rencana yang telah disusun. Dalam tahap yang ke-6 ini juga direncanakan pada tahap penelitian yang ke-2. 
7. Mendokumentasikan Hasil dan Hal Yang Dipelajari (Documenting Outputs, Outcomes and Learning)

Untuk tahap yang ke-7 inipun direncanakan pada tahap penelitian yang ke-2 nantinya.

\section{SIMPULAN DAN SARAN}

\section{SIMPULAN}

a. Faktor-faktor yang menyebabkan tidak berfungsinya PKPBDD dan pabrik pengolahan jus dan sirup adalah pertama tidak adanya rasa memiliki dari para anggotanya. Kedua, koperasi tersebut tidak mampu menampung semua hasil panen petani. Ketiga, sebagai pusat koperasi seharusnya terdiri dari 3 koperasi primer, sedangkan PKPBDD tidak mempunyai.

b. Faktor-faktor yang menyebabkan Pemkot Depok belum berhasil dalam menjadikan Kelurahan Pasir Putih sebagai lokasi primatani dan kawasan model agrowisata belimbing adalah pertama, menurunnya partisipasi masyarakat. Kedua, adalah kurangnya koordinasi antar lintas sektor. Ketiga, adalah karena belum adanya pariwisata berbasis masyarakat.

c. Model pemberdayaan masyarakat yang cocok untuk diterapkan agar masyarakat Kel. Pasir Putih terlibat aktif dalam pengembangan agrowisata belimbing dewa adalah Pendekatan 7D.

d. Dari inventarisasi potensi agrowisata yang telah dilakukan di Kelurahan Pasir Putih, ditemukan sebanyak 9 buah, atraksi wisata sebanyak 17 buah, aksesbilitas sebanyak 2 buah dan amenities sebanyak 8 buah.

\section{SARAN}

a. Sebaiknya koperasi dibentuk oleh petani dari petani dan untuk petani atau bottom up, sehingga keputusan yang diambil hanya untuk kesejahteraan anggota.

b. Sebaiknya koperasi dididirikan menggunakan modal yang berasal dari simpanan pokok, simpanan wajib dan simpanan sukarela anggota baru ditambah dengan bantuan dari berbagai pihak, sehingga anggota akan mempunyai rasa memiliki yang tinggi untuk mengembangkan koperasi.

c. Sebaiknya pusat koperasi harus terdiri dari 3 koperasi primer, sehingga akan menjadi lebih kuat.

d. Sebaiknya koperasi mempunyai tim pemasaran yang tangguh, sehingga mempunyai pasar sasaran yang luas sehingga mampu menampung semua pasokan belimbing dari anggota.

e. Agar tujuan Pemkot Depok dalam menjadikan Kelurahan Pasir Putih sebagai lokasi primatani dan kawasan model agrowisata belimbing, maka sebaiknya 
diciptakan pariwisata berbasis masyarakat, dimana syarat utamanya adalah keterlibatan dari masyarakat local.

f. Agar pemberdayaan masyarakat dalam agrowisata belimbing dewa di Kelurahan Pasir Putih dapat tercapai maka diperlukan penerapan Model Pendekatan 7D secara serius dan terfokus, agar tujuan dari masing-masing tahapan tercapai.

g. Permasalahan yang paling serius dihadapi adalah berkurangnya lahan hijau yang digunakan sebagai lahan pertanian belimbing secara terus menerus, sehingga kebijakan yang harus dibuat terlebih dahulu adalah menghentikan perizinan bagi para pengembang property, sebab jika hal ini tidak dilakukan sudah dipastikan dalam hitungan beberapa tahun ke depan, Belimbing Dewa pasti punah.

h. Dari potensi agrowisata yang telah diiventarisasi, hal tersebut merupakan modal utama yang harus segera dikembangkan yang akan menjadi cikal bakal dari agrowisata yang berkelanjutan

i. Dalam pembuatan kebijakan dan program pengembangan agrowisata dibutuhkan koordinasi tingkat tinggi antar lintas sektor dari dinas terkait, yaitu Dinas Pariwisata, Dinas Tata Ruang dan Kota, Dinas Pertanian dan Dinas Perindustrian dan Perdagangan, sehingga semua mempunyai visi dan misi yang sama.

j. Melihat perkembangan Kota Depok yang semakin banyak tumbuhnya obyekobyek wisata baru seperti Kampung Pepohonan 99, Masjid Kubah Mas, Setu di daerah Jalan Wahab kemudian desa wisata yang terdapat di daerah Limo, Cinere serta adanya Kampung Betawi Setu Babakan di Jagakarsa,Jaksel, sebaiknya Depok dijadikan Kawasan Pusat Pengembangan Pariwisata Terpadu.

\section{DAFTAR PUSTAKA}

Argowisata. (2007). Diakses dari http:/www..deptan.go.id.

Argowisata. (2007). Diakses dari http:/www.farmstop.com.

Gaol, H, L., \&, Pitana, I.G. (2006). Pengembangan Sinergis Antara sektor Pertanian Dengan Pariwisata. Jurnal Kepariwisataan Indonesia. Vol.1, No.3, September 2006, hal : 167-184

Mason, P. (2006). Tourism Impacts, Planning and Management. Elseiver Butterworth-Heinemann.Oxford

Maetzold, J. A. (2002). Nature-Based Tourism and Agritourism Trends: Unlimited Opportunities. National Alternatif Enterprises and Agritourism Leader, 
USDA/NRCS, Washington, DC

Natori, M. (2001). A Guide Book for Tourism-Based Community Development. Yokohama : Asia Pasific Tourism Exchange Center

Prasiasa, D, P, O. (2013). Destinasi Pariwisata Berbasis Masyarakat. Salemba Humanika Jakarta

Prasiasa, D, P, O. (2010). Pengembangan Desa Wisata Jatiluwih Kabupaten Tabanan. Denpasar Universitas Udayana

Slamet, Y. (1993). Pembangunan Masyarakat Berwawasan Partisipasi. Surakarta : Sebelas Maret University Press

Yoeti, Oka, A. (2008). Perencanaan \& Pengembangan Pariwisata. PT Pradnya Paramita Jakarta

Yoeti, Oka A. (2005). Perencanaan Strategis Pemasaran Daerah Tujuan Wisata. PT Pradnya Paramita Jakarta 